\title{
Pengaruh Bauran Promosi dan Physical Evidence terhadap Keputusan Pengunjung pada Candi Muara Jambi
}

\author{
Fiza Fradesa \\ Prodi Manajemen FE Universitas Batanghari \\ Correspondence email: fizafradesa97@gmail.com
}

\begin{abstract}
This study raised concerns about the influence of the promotion mix and physical evidence that will have an impact on visitor decisions. This research was conducted in the exact scope of the Muara Jambi Temple. The visitor's decision is one of the main problems that are always faced by various tourist attractions. Therefore, it is important for tourist attractions to increase promotion and physical evidence to provide what visitors want. The purpose of this study was to determine the effect of the promotion mix, physical evidence, and visitor decisions on the Muara Jambi Temple, to determine the effect of the promotional mix and physical evidence on simultaneous visitor decisions on the Muara Jambi Temple, and to determine the effect of the promotional mix and physical evidence on visitor's decision partially at the Muara Jambi Temple. To check the problem above the survey was conducted by distributing questionnaires to the visitors of the temple. The results of the questionnaire were analyzed descriptively and verifiatively. The analytical tool in this study uses multiple linear regression with proof of hypothesis by $F$ statistical tests and $t$ statistical tests. The results of this study indicate that the statistical test $F$ variable promotional mix $\left(X_{1}\right)$ has an influence on visitor decisions, while the physical evidence variable $\left(\mathrm{X}_{2}\right)$ has no influence on visitor decisions.
\end{abstract}

Keywords: Promotion Mix; Physical Evidence; Visitor Decisions

\section{PENDAHULUAN}

Dewasa ini sektor industri merupakan salah satu sektor yang berperan penting dalam pembangunan nasional.Kontribusi sektor industri terhadap pembangunan nasional dari tahun ke tahun menunjukkan kontribusi yang signifikan.Peranan sektor industri dalam Pembangunan Ekonomi Nasional dapat ditelusuri dari kontribusi masing-masing subsektor terhadap Laju Pertumbuhan Ekonomi Nasional atau terhadap produk domestik bruto.Dari sekian banyak sektor industri yang ada di Indonesia, sektor pariwisata juga mempunyai andil besar terhadap pembangunan perekonomian baik itu secara nasional maupun daerah.

Pembangunan pariwisata menjadi sektor andalan yang mampu menggerakkan sektor-sektor ekonomi lain yang berkaitan erat. Pariwisata juga merupakan kegiatan yang strategis jika ditinjau dari segi pengembangan ekonomi dan sosial budaya karena kepariwisataan mendorong terciptanya lapangan pekerjaan, peningkatan pendapatan masyarakat, dan peningkatan kualitas masyarakat.Pariwisata juga menjadi salah satu mesin penggerak perekonomian dunia yang terbukti mampu memberikan kontribusi terhadap kemakmuran sebuah Negara.Pembangunan pariwisata mampu menggairahkan aktivitas bisnis untuk menghasilkan manfaat sosial, budaya, dan ekonomi yang signifikan bagi suatu Negara. Ketika pariwisata direncanakan dengan baik, mestinya kan dapat memberikan manfaat bagi masyarakat pada sebuah destinasi. Keberhasilan pariwisata terlihat dari penerimaan pemerintah dari sektor pariwisata dapat mendorong sektor lainnya untuk berkembang.

Saat ini, kegiatan dalam bidang pemasaran memiliki peranan yang penting dalam dunia bisnis, hal ini disebabkan karena pemasaran merupakan salah satu kegiatan yang dilakukan oleh produsen dimana produsen berhubungan langsung dengan konsumen. Kegiatan pemasaran ini harus memberikan kesan yang baik di mata konsumen atau pengunjung, di mana produsen harus memberikan layanan serta hasil produk berupa barang dan jasa yang terbaik sehingga dapat memberikan kepuasan kepada para konsumen atau pengunjung, karena kepuasan konsumen atau pengunjung menjadi tolak ukur keberhasilan suatu perusahaan atau lembaga instansi dalam mengasilkan produk yang berkualitas dan yang dapat memenuhi kebutuhan dan keinginan konsumen atau pengunjung. Peranan pemasaran saat ini tidak hanya menyampaikan produk atau jasa hingga tangan konsumen tetapi juga bagaimana produk atau jasa tersebut dapat memberikan kepuasan kepada pelanggan dengan menghasilkan laba.Sasaran dari pemasaran adalah menarik pengunjung baru dengan menjanjikan nilai kepada pengunjung, menetapkan harga menarik, mendistribusikan produk dengan mudah, mempromosikan secara efektif dan efisien serta mempertahankan pelanggan yang sudah ada dengan tetap memegang prinsip kepuasan pelanggan/pengunjung.Bauran pemasaran (marketing mix) produk kita kenal dengan istilah 4P (product, price, place dan promotion) sedangkan untuk bauran pemasaran jasa kita kenal dengan istilah 7P (product, price, place, promotion, people, physical evidence, dan process. Pada penelitian ini penulis menggunakan bauran pemasaran jasa yakni promotion (promosi) dan physical Evidence (bukti fisik).

Promosi menjadi salah satu bagian dari pemasaran yakni kegiatan yang ditujukan untuk mempengaruhi pengunjung agar mereka dapat menjadi kenal akan jasa wisata yang ditawarkan kepada pengunjung dan 
kemudian mereka menjadi tertarik akan jasa tersebut lalu mengunjunginya. Maka dari itu promosi yang baik menentukan keberhasilan suatu produsen dalam mencapai tujuannya.

Bersamaan dengan adanya perubahan lingkungan yang terjadi dan adanya perubahan perilaku manusia, serta aktivitas manusia yang semakin padat setiap harinya, maka semakin mendorong bertambahnya permintaan akan kebutuhan rekreasi. Kabupaten Muaro Jambi merupakan salah satu kabupaten di wilayah Provinsi Jambi yang memiliki objek dan daya tarik wisata, antara lain objek wisata candi dan objek wisata budaya. Berbagai macam objek dan daya tarik wisata yang ada di Kabupaten Muaro Jambi mempunyai potensi yang cukup baik yang dapat memberikan pemasukan bagi pendapatan daerah salah satu nya adalah tempat peninggalan purbakala terluas di Indonesia Yaitu Candi Muara Jambi.Situs purbakala yang terdapat di kawasan Desa Muaro Jambi, Kecamatan Maro Sebo Ulu, Kabupaten Muaro Jambi ini, diprediksikan sudah berdiri kokoh pada abad ke-11 Masehi.Dimana pada saat itu masih berada di bawah masa pemerintahan Sriwijaya dan hingga saat ini candi tersebut masih utuh dan dan terawat dengan baik.

Tak hanya itu, Candi ini merupakan salah satu warisan budaya agama Budha yang bernilai sangat tinggi. Dimana pada bagian-bagian yang terdapat pada bangunan Candi tersebut dapat menunjukkan bahwa Candi Muara Jambi dijadikan sebagai salah satu pusat tempat peribadatan agama Buddha di Indonesia, salah satunya seperti kegiatan ashada, meditasi, napak tilas astisha, bahkan beberapa situs dijadikan pusat perayaan hari raya Waisak yang masuk di dalam agenda Nasional disamping Candi Borobudur.

Dinas Kebudayan dan Pariwisata Provinsi Jambi sudah mendaftarkan Candi bersejarah ini sebagai salah satu warisan dunia pada UNESCO di Perserikatan Bangsa-Bangsa (PBB).Langkah tersebut merupakan salah satu upaya untuk menjadikan Candi Muara Jambi ini sebagai salah satu warisan dunia. Dampak positif yang langsung terasa dari pengajuan tersebut, kunjungan wisatawan akan meningkat di wilayah Provinsi Jambi. Selain itu, para sastrawan, ilmuwan, serta para penulis akan banyak yang berdatangan untuk dapat meneliti dan juga menulis mengenai Candi ini. Hal ini juga diperkuat dengan adanya beberapa hasil temuan benda sejarah yang terdapat pada Candi, seperti halnya hasil reruntuhan Stupa, Arca Gajah Singh, Arca Prajinaparamita dan lain sebagainya.Selain menyuguhkan tempat wisata yang mempunyai nilai sejarah yang tinggi, harga tiket masuk ke candi ini juga relatif murah yang dapat dijangkau oleh semua kalangan.

Namun disamping kelebihannya, Candi Muara Jambi juga memiliki kelemahan diantaranya promosi yang masih kurang menjangkau masyarakat, fasilitas yang belum maksimal, yakni tidak ada tempat duduk untuk pengunjung, tidak ada gasebo atau tempat berteduh untuk pengunjung dikala hujan turun, tidak ada petugas toilet yang standbye dilokasi, tempat parkir yang kurang luas dan jalan ke lokasi wisata masih banyak yang rusak.

\section{Tinjauan Pustaka}

\section{Bauran Promosi}

Bauran promosi menurut Indriyo Gitodusarmo (2012:159) adalah kegiatan yang ditujukkan untuk mempengaruhi konsumen agar mereka dapat menjadi kenal akan produk yang ditawarkan oleh perusahaan kepada mereka dan kemudian mereka menjadi tertarik akan produk tersebut lalu membelinya.

Djaslim Saladin (2003:172) menyatakan bahwa: "Bauran promosi adalah kombinasi dari penjualan tatap muka, periklanan, promosi penjualan, publisitas, dan hubungan masyarakat yang membantu pencapaian tujuan perusahaan".

Menurut Philip Kotler dan Gary Armstrong dalam H. Abdul Manap (2016:304) indikator bauran promosi adalah sebagai berikut: 1. Promosi periklanan (advertising),2. Promosi penjualan (sales promotion),3. Promosi hubungan masyarakat dan publisitas (public relation and publicity),dan4.Promosi personal (personal selling).

\section{Physical Evidence}

Sarana Fisik (Physical Evidence) dari penelitian Zeithaml, Bitner, Mary dan Dwayne (2009) adalah lingkungan pelayanan perusahaan dan pelanggan saling berinteraksi dan komoditi nyata/berwujud yang memfasilitasi performa/komunikasi pelayanan.

Sedangkan menurut Nirwana (2004:47) Physical Evidence merupakan fasilitas pendukung bagian dari pemasaran jasa yang memiliki peranan cukup penting, karena jasa yang disampaikan kepada pelanggan tidak jarang memerlukan fasilitas pendukung di dalam penyampaiannya.

Lupiyoadi, Rambat \& Hamdanai (2009:71) menyatakan bahwa "bukti fisik (phisyical evidence) merupakan lingkungan fisik tempat jasa diciptakan dan langsung berinteraksi dengan konsumen".

Adapun indikator yang dikemukakan oleh Zeithaml dan Bitner dalam Wijaya (2012) ini adalah sebagai berikut: 1) Perancangan fasilitas, 2) Peralatan, 3) Petunjuk, 4) Seragam, dan 5) Bentuk berwujud lainnya.

\section{Keputusan Pengunjung}

Pengambilan keputusan adalah suatu proses penentuan keputusan yang terbaik dari sejumlah alternatif untuk melakukan aktivitas-aktivitas pada masa yang akan datang (Hasibuan, 2011:55).

Menurut Siagian pengambilan keputusan adalah suatu pendekatan yang sistematis terhadap hakikat alternatif yang dihadapi dan mengambil tindakan yang menurut perhitungan merupakan tindakan yang paling tepat (dalam Hasan, 2002:10). 
Adapun indikator Keputusan Pengunjung menurut I Ketut Suwena dan I Gusti Widyatmamaja (2017:67) adalah sebagai berikut: 1 . Gaya hidup (pendapatan dan pekerjaan, hak cuti kerja, pendidikan dan mobility, ras dan jenis kelamin), dan 2.Siklus umur (childhood, adolescence, marriade, empty nest stage/old age).

\section{METODE}

Penelitian ini menggunakan pendekatan deskriptif kuantitatif dengan bentuk penelitian korelasional.Penelitian ini dimaksudkan untuk mengetahui keterkaitan antara setiap variabel bebas dengan variabel terikat.Objek penelitian ini adalah seluruh populasi pengunjung yang ada di Candi Muara Jambi yang berjumlah 108.677 orang pada tahun 2017 . Dan sampel yang digunakan dengan menggunakan teknik simple random sampling, yakni pengambilan sampel dari populasi dilakukan secara acak tanpa memperhatikan strata yang ada dalam populasi itu.Adapun sampel yang didapat menggunakan rumus Slovin sehingga mendapatkan hasil perhitungan sampel sebanyak 100 orang. peneliti menggunakan angket (kuesioner) dengan rincian pada variabel bauran promosi berjumlah 10 item pertanyaan, variabel physical evidence berjumlah 12 item pertanyaan, dan keputusan pengunjung berjumlah 8 item pertanyaan.

Prosedur pengumpulan data yaitu responden diberikan waktu untuk mengisi kuesioner selama 30 sampai dengan 45 menit dan diperkenankan untuk mengklarifikasi pernyataan yang kurang jelas.Setelah selesai kuesioner dikumpulkan dan peneliti melakukan pengecekan terhadap kelengkapan dan kejelasan isian kuesioneruntuk memastikan semua pernyataan telah terisi.Selanjutnya mengumpulkan kesioner-kuesioner yang telah di isi responden ke dalam satu berkas.Namun apabila tidak semua responden mengisi pada saat itu juga, dikarenakan aktivitas responden yang tinggi sehingga beberapa kuesioner ada yang dibawa pulang untuk diambil di hari berikutnya.

Dalam penelitian untuk menganalisis data yang diperoleh secara deskriptif kuantitatif.Analisis dilakukan berdasarkan teori yang mempunyai kaitan erat dengan aspek yang diteliti.Analisis deskriptif kualitatif merupakan penyesuaian keadaan sebenarnya dan menggambarkan karakteristik peristiwa yang diamati serta menyimpulkan secara benar dan menyeluruh berdasarkan metode ilmiah dan menggunakan teori-teori yang dipelajari dan konsep yang relevan dalam permasalahan sebagai landasan berpijak dalam menganalisis.

Untuk menganalisis permasalahan yang ada digunakan skala penelitian dengan menghitung frekuensi skor setiap item pertanyaan atau dengan skala likert.Dalam arti bahwa perhitungan skor setiap komponen yang diteliti dengan mengalihkan seluruh frekuensi data dengan nilai bobot.Untuk melihat bagaimana hubungan variabel independen dan variabel dependen, maka dilihat berdasarkan koefisien determinasi (R2).Yang mana koefisien determinasi merupakan angka yang menyatakan atau digunakan untuk mengetahui kontribusi atau sumbangan yang diberikan oleh sebuah variabel bebas terhadap variabel terikat.Secara sederhana koefisien determinasi dihitung dengan mengkuadratkan koefisien korelasi (r).

Dilain sisi untuk melihat pengaruh dari variabel independen terhadap variabel dependen maka digunakan dalam bentuk pengujian statistik yakni uji $\mathrm{F}$ dan uji $\mathrm{t}$. Pada uji ini menyatakan apabila hasil $\mathrm{t}$ yang dihitung lebih besar dari t dalam tabel, maka dapat dinyatakan ada pengaruh variabel independen terhadap variabel dependen, begitupun sebaliknya.

\section{HASIL DAN PEMBAHASAN Hasil}

Berdasarkan distribusi variabel bauran promosi dapat dijelaskan bahwa semua variabel bauran promosi mempunyai skor rata-rata yaitu 278,2 dalam kategori cukup baik. Dengan keterangan skor dimensi promosi periklanan 379,6 kategori cukup baik, skor dimensi promosi penjualan 243,5 kategori tidak baik, serta skor dimensi promosi masyarakat dan publisitas 299 kategori cukup baik. Semua variabel physical evidence mempunyai skor rata-rata yaitu 262,75 dalam kategori cukup baik. Dengan keterangan skor dimensi perancangan fasilitas 250 kategori tidak baik, skor dimensi peralatan 337 kategori cukup baik, skor dimensi petunjuk 257,3 kategori tidak baik, skor dimensi seragam 258,5 kategori tidak baik, dan skor dimensi bentuk berwujud lainnya 220 kategori tidak baik. Dilain sisi untuk semua variabel keputusan pengunjung mempunyai skor rata-rata yaitu 370,37 dalam kategori baik dengan keterangan skor dimensi pekerjaan 374 kategori baik, skor dimensi hobi 385 kategori baik, skor dimensi minat 398 kategori baik, skor dimensi childhood 355 kategori baik, skor dimensi adolescence/young adult 368 kategori baik, skor dimensi marriade 361 kategori baik, dan skor dimensi empty nest stagelold age 354 kategori baik.

Sehubungan dengan data yang didapat adalah data primer, maka data tersebut harus diuji dalam bentuk uji validasi dan uji reliabilitas.Uji tersebut masing-masing untuk mengetahui akurasi data yang dikumpulkan dari penggunaan instrument.data penelitian tidak bermanfaat apabila instrument yang digunakan untuk mengumpulkan data penelitian tidak memiliki reliabilitas dan validitas yang tinggi. Berdasarkan hasil perhitungan diketahui $\mathrm{f}_{\text {hitung }} 2,840<\mathrm{f}_{\text {tabel }} 3,09$. Disisi lain variabel $X_{1} t_{\text {hitung }} 1,878>X_{1} t_{\text {tabel }} 1.66071$ dan $X_{2} t_{\text {hitung }}$ $1,474<X_{2} t_{\text {tabel }}$ 1.66071, ini memberi makna bahwa semua data dari variabel dependen maupun variabel independen dapat digunakan atau semua data valid.

Selanjutnya regresi linear berganda pada penelitian ini digunakan dalam penelitian ini dengan tujuan untuk memasukkan data yang diteliti kedalam 
suatu model persamaan regresi dan membuktikan mengenai dugaan adanya pengaruh signifikan antara variabel independen (promosi dan physical evidence) terhadap variabel dependen (keputusan pengunjung). Berdasarkan hasil analisis regresi linear berganda (lampiran) dapat diperoleh model persamaan regresi linear bergandanya sebagai berikut: $\mathbf{Y}=\mathbf{2 7 , 0 2 2}+\mathbf{0 , 3 7 2}$ X1 - 0,261 X2. Koefisien regresi variabel independen $\mathrm{X}_{1}$ (bauran promosi) sebesar 0,372 dan nilai yang positif menunjukkan bahwa bauran promosi $\left(\mathrm{X}_{1}\right)$ berpengaruh positif terhadap keputusan pengunjung (Y).Sedangkan koefisen regresi variabel $\mathrm{X}_{2}$ (physical evidence) sebesar 0,261 dan nilai negatif menunjukkan bahwa physical evidence $\left(\mathrm{X}_{2}\right)$ tidak berpengaruh terhadap keputusan pengunjung $(\mathrm{Y})$.

Dari hasil pengujian SPPS uji $F$ terlihat bahwa nilai $\mathrm{F}$ hitung lebih kecil dari pada $\mathrm{F}$ tabel $(2,840<3,09)$ dapat diartikan bahwa variabel Bauran Promosi dan Physical Evidenceberpengaruh secara signifikan terhadap Keputusan Pengunjung. Uji statistik t digunakan untuk mengetahui apakah variabel independen mempengaruhi secara signifikan terhadap variabel dependen. Dengan menggunakan tingkat signifikan $\alpha=5 \%$ (signifikansi 0,05 adalah ukuran standar yang sering digunakan dalam penelitian). Uji t, pada variabel bauran promosi terdapat berpengaruh signifikan terhadap keputusan pengunjung, terlihat bahwa nilai $\mathrm{t}$ hitung lebih besar dari pada $\mathrm{t}$ tabel (1,878>1,66071), maka $\mathrm{H}_{0}$ ditolak dan $\mathrm{H}_{1}$ diterima dan pada variabel Physical Evidence tidak terdapat pengaruh signifikan Terhadap Keputusan pengunjung, terlihat bahwa nilai $\mathrm{t}$ hitung lebih kecil dari pada $\mathrm{t}$ tabel ($1,474<1,66071)$, maka $\mathrm{H}_{0}$ diterima dan $\mathrm{H}_{1}$ ditolak.

Koefisien korelasi antara bauran promosi $\left(\mathrm{X}_{1}\right)$ dan physical evidence $\left(\mathrm{X}_{2}\right)$ terhadap keputusan pengunjung (Y) adalah 0,235 artinya terdapat hubungan yang tidak erat antara variabel bauran promosi $\left(\mathrm{X}_{1}\right)$ dan physical evidence $\left(\mathrm{X}_{2}\right)$ terhadap keputusan pengunjung $(\mathrm{Y})$. Dari hasil pengujian model summary maka diperoleh nilai (Adjusted $\mathrm{R}$ Square) $\mathrm{r}^{2}$ sebesar 0,036 angka ini menyatakan bahwa besarnya konstribusi variabel bauran promosi $\left(\mathrm{X}_{1}\right)$ dan physical evidence $\left(\mathrm{X}_{2}\right)$ terhadap keputusan pengunjung (Y) 3,6\% sisanya 100\% - 3,6\% = $96,4 \%$ dipengaruhi variabel lain yang tidak kita teliti pada penelitian ini.

\section{Pembahasan}

Dalam pembahasan ini ada beberapa pokok bahasan yang akan di uraikan yakni sebagai berikut:

\section{Bauran Promosi Candi Muara Jambi}

Tabel 1. Rekap Jawaban Dimensi Bauran Promosi

\begin{tabular}{clcc}
\hline No. & \multicolumn{1}{c}{ Pertanyaan } & Skor & Keterangan \\
\hline 1. & Dimensi Promosi Periklanan & 379,6 & Cukup Baik \\
2. & Dimensi Promosi Penjualan & 243,5 & Tidak Baik \\
3. & $\begin{array}{l}\text { Dimensi Promosi Masyarakat } \\
\text { dan Publisitas }\end{array}$ & 299 & Cukup Baik \\
\hline
\end{tabular}

Sumber: Data primer (diolah)
Berdasarkan keterangan diatas diketahui bahwa jawaban responden tertinggi berkaitan dengan dimensi promosi periklanan sebesar 379,6, sedangkan jawaban terendah berkaitan dengan dimensi promosi penjualan sebesar 243,5. Bauran promosi rata-rata skornya 278,2 mendapat predikat cukup baik dengan sub indikator media sosial membantu pengunjung dalam mengetahui objek wisata Candi Muara Jambi mendapat skor tertinggi 335. Rata-rata physical evidence 262,75 mendapat predikat cukup baik dengan sub indikator penyewaan sepeda menarik pengunjung mendapat skor tertinggi 338. Keputusan pengunjung rata-rata skornya 370,37 mendapat predikat baik dengan sub indikator minat yang pengunjung miliki membuat pengunjung tertarik mengunjungi objek wisata Candi Muara Jambi dengan perolehan skor tertinggi 398.

\section{Physical Evidence Candi Muara Jambi}

Tabel 2. Rekap Jawaban Dimensi Physical Evidence

\begin{tabular}{clcc}
\hline No. & \multicolumn{1}{c}{ Pertanyaan } & Skor & Keterangan \\
\hline 1. & Dimensi Perancangan Fasilitas & 250 & Tidak Baik \\
2. & Dimensi Peralatan & 337 & Cukup Baik \\
3. & Dimensi Petunjuk & 257,3 & Tidak Baik \\
4. & Dimensi Seragam & 258,5 & Tidak Baik \\
5. & Dimensi Bentuk Berwujud & 220,5 & Tidak Baik \\
& Lainnya & & \\
\hline
\end{tabular}

Sumber: Data primer (diolah)

Berdasarkan keterangan diatas diketahui bahwa jawaban responden tertinggi berkaitan dengan dimensi peralatan sebesar 337, sedangkan jawaban terendah berkaitan dengan dimensi bentuk berwujud lainnya sebesar 220,5. Rata-rata skornya sebesar 262,75 artinya physical evidence pada Candi Muara Jambi selama ini cukup baik. Diketahui juga skor jawaban tertinggi ada pada sub indikator peralatan yakni penyewaan sepeda dapat menarik pengunjung dengan perolehan skor 338 . Sedangkan skor jawaban terendah ada pada sub indikator bentuk berwujud lainnya yakni lokasi wisata Candi Muara Jambi dilengkapi dengan kursi atau gasebo dengan perolehan skor 205 .

\section{Keputusan Pengunjung Candi Muara Jambi}

Tabel 3. Rekap Jawaban Keputusan Pengunjung

\begin{tabular}{clcc}
\hline No. & \multicolumn{1}{c}{ Pertanyaan } & Skor & Keterangan \\
\hline 1. & Dimensi Pekerjaan & 374 & Baik \\
2. & Dimensi Hobi & 385 & Baik \\
3. & Dimensi Minat & 398 & Baik \\
4. & Dimensi Chilhood & 355 & Baik \\
5. & Dimensi Adolescence & 368 & Baik \\
& $\begin{array}{l}\text { (Young Adult) } \\
\text { 6. }\end{array}$ & & \\
7. Dimensi Marriade & 361 & Baik \\
& Dimensi Empty Nest & 354 & Baik \\
& Stage/Old Age & & \\
\hline
\end{tabular}

Sumber: Data primer (diolah) 
Berdasarkan keterangan diatas diketahui bahwa jawaban responden tertinggi berkaitan dengan dimensi minat sebesar 398, sedangkan jawaban terendah berkaitan dengan dimensiempty nest stagelold age sebesar 354. Rata-rata skornya sebesar 370,37 artinya keputusan pengunjung pada Candi Muara Jambi selama ini sudah baik.

\section{Pengaruh Bauran Promosi dan Physical Evidence Terhadap Keputusan Pengunjung Pada Candi Muara Jambi}

\section{Uji F dan Uji $t$}

Hipotesis menyatakan bahwa Bauran Promosi dan Physical Evidence berpengaruh secara parsial dan signifikan terhadap Keputusan pengunjung Pada Candi Muara Jambi. Berikut hasil pengujiannya :

Tabel 4. Nilai F hitung dan F tabel Bauran Promosi dan Physical Evidence Terhadap Keputusan Pengunjung

\begin{tabular}{cccc}
\hline Variabel & F hitung & F tabel & Sig. \\
\hline Bauran Promosi dan Physical & 2,840 & 3,09 & $.063^{\mathrm{b}}$
\end{tabular}

Evidence

Sumber: Data diolah

Pada tabel di atas, dapat diketahui bahwa nilai $\mathrm{F}$ hitung sebesar 2,840, nilai $\mathrm{F}$ tabel sebesar 3,09, dannilai signifikan 0,063. Nilai $F$ hitung $<$ nilai $F$ tabel $(2,840<3,09)$, maka hipotesis yang menyatakan bahwa Bauran promosi dan Physical Evidence berpengaruh secara bersama-sama dan signifikan terhadapkeputusan pengunjung pada Candi Muara Jambi diterima. Hipotesis menyatakan bahwa Bauran Promosidan Physical Evidence berpengaruh secara parsial dan signifikan terhadap Keputusan Pengunjung pada Candi Muara Jambi. Berikut hasil pengujiannya:

Tabel 5. Nilai t hitung dan t tabel Bauran Promosi dan Physical Evidence Terhadap Keputusan Pengunjung

\begin{tabular}{cccc}
\hline \multicolumn{1}{c}{ Variabel } & $\mathrm{t}$ hitung & $\mathrm{t}$ tabel & Sig. \\
\hline Bauran Promosi & 1,878 & 1,66071 & .063 \\
Physical Evidence & $-1,474$ & 1,66071 & .144 \\
\hline Sumber: Data diolah & & &
\end{tabular}

Pada tabel di atas, dapat diketahui bahwa :

a. Nilai t hitung untuk bauran promosi sebesar 1,878 , nilai $\mathrm{t}$ tabel sebesar 1,66071, dan nilai Signifikan 0,063 . Nilai $t$ hitung > nilai t tabel $(1,878>1,66071)$, maka hipotesis yang menyatakan bahwa bauran promosi berpengaruh secara parsial dan signifikan terhadap keputusan pengunjung pada Candi Muara Jambi diterima.

b. Nilai t hitung untuk Physical evidence sebesar -1,474, nilai $t$ tabel sebesar 1,66071, dan nilai Signifikan 0,144 . Nilai t hitung < nilai $t$ tabel $(-1,474<1,66071)$, maka hipotesis yang menyatakan bahwa physical evidencetidak berpengaruh secara parsial dan tidak signifikan terhadapkeputusan pengunjung pada Candi Muara Jambi ditolak..

Hipotesis menyatakan bahwa Bauran Promosi berpengaruh secara signifikan terhadap keputusan pengunjung, sedangkan Physical Evidence tidak memiliki pengaruh signifikan terhadap keputusan pengunjung pada Candi Muara Jambi.

\section{SIMPULAN}

1. Bauran Promosi dan Physical Evidence berpengaruh secara parsial dan signifikan terhadap Keputusan Pengunjung Pada Candi Muara Jambi.

2. Bauran Promosi berpengaruh secara simultan dan signifikan terhadap Keputusan Pengunjung Pada Candi Muara Jambi.

3. Physical Evidencetidak berpengaruh secara simultan dan signifikan terhadap Keputusan Pengunjung Pada Candi Muara Jambi.

4. Bauran promosi dan physical evidence terhadap keputusan pengunjung pada Candi Muara Jambi dengan persamaan regresi $\mathrm{Y}=27,022+0,372 \mathrm{X} 1-$ $0,261 \times 2$.

5. Dari hasil pengujian model summary maka diperoleh nilai (Adjusted $\mathrm{R}$ Square) $\mathrm{r}^{2}$ sebesar 0,036 angka ini menyatakan bahwa besarnya konstribusi variabel bauran promosi $\left(\mathrm{X}_{1}\right)$ dan physical evidence $\left(\mathrm{X}_{2}\right)$ terhadap keputusan pengunjung $(\mathrm{Y})$ 3,6 \% sisanya $100 \%-3,6 \%=96,4 \%$ dipengaruhi variabel lain yang tidak kita teliti pada penelitian ini.

\section{Saran}

1. Promosi Candi Muara Jambi selama ini masih belum cukup baik, dilihat pada indikator penggunaan baliho masih dalam taraf tidak baik. Dalam hal ini pihak Candi harus lebih meningkatkan bauran promosi Candi khususnya memasang baliho disetiap kegiatan/event agar pengunjung tertarik dan mengetahui kegiatan/event yang diselenggarakan pihak Candi.

2. Physical EvidenceCandi Muara Jambi belum cukup baik, dilihat indikator bentuk berwujud lainnya, yakni penyediaan sarana kursi atau gasebo Candi masih dalam taraf tidak baik. Dalam hal ini pihak Candi harus lebih memaksimalkan sarana dan prasarana Candi khususnya penyediaan kursi atau gasebo di Candi demi kenyamanan pengunjung guna meningkatkan jumlah kunjungan pada Candi Muara Jambi.

\section{DAFTAR PUSTAKA}

Aksara.Pitana, I Gde dan Surya Diarta I Ketut. 2009. Pengantar Ilmu Pariwisata. Yogyakarta: Andi.

Ardika, I Wayan. 2007. Dampak Pariwisata terhadap Situs dan Peninggalan Arkeologi di Bali. Laporan Penelitian Universitas Udayana. 
Arikunto, S. 2006. Prosedur Penelitian : Suatu Pendekatan Praktik. Penerbit Rineka Cipta. Jakarta.

Asnawi, Tetty. 2011. Dasar-dasar Pemasran, edisi pertama, cetakan pertama. Palembang: Citrabooks Indonesia

Basu, Swastha, 2001, Manajemen Pemasaran Modern: Yogyakarta. BPKE

Djaslim, Saladin, 2003: Manajemen Pemasaran, Bandung, Linda Karya

Danang, Sunyoto. 2012. Dasar-dasar Manejemen Pemasaran, cetakan pertama. Caps. Yogyakarta

Ferdinand, Augusty. 2006. Metode Penelitian Manajemen. Badan Penerbit Universitas Diponegoro : Semarang

Gitosudarmo, Indriyo, 2008, Manajemen Pemasaran, edisi kedua, cetakan keenam,Penerbit : BPFE Yogyakarta

Hapzi Ali, 2013, Metodologi Penelitian, Depiblish, Yogyakarta Persada, Jakarta

Husen Umar. 2005. Metode Penelitian. Salemba empat : Jakarta

Ketut, I Suwena, I Gst Ngr Widyatmaja. 2017. Pengetahuan Dasar Ilmu Pariwisata. Denpasar: Pustaka Larasan

Kountur, Ronny.Metode Penelitian Untuk Penulisan Skripsi dan Tesis Edisi Revisi. 2007. PPM. Jakarta.

Kotler, Philip. 2002. Manajemen Pemasaran: Jilid 1. Edisi Milenium. Jakarta. Prehallindo.

Kotler, Philip and Keller K Lane. 2009. Marketing Management, Thirteen Edition, Jeresey: Prentice Hall.

Lupiyoadi, Rambat, 2013, Manajemen Pemasaran Jasa. Jakarta: PT. Salemba Empat.

Manap, H. A. (2016). Revolusi Manajemen Pemasaran. Jakarta: Mitra Wacana Media.

Mardalis. 2010. Metode Penelitian (Suatu Pendekatan Proposal). Jakarta: Bumi

Novena.2013. Fakultas Ekonomi dan Bisnis Universitas Diponegoro Semarang. "Pengaruh Bauran Promosi Terhadap Keputusan Kunjungan Konsumen Pariwisata (Studi Kasus pada Objek Wisata Umbul Sidomukti, Kabupaten Semarang)".

Utama, I Gusti Bagus Rai. 2017. Pemasaran Pariwisata.Yogyakarta: CV. Andi Offset

Zeithaml, dan Bitner, 2005, Relationship Marketing. Jurnal Dr. Sudirman Zaid, 2006. Jurnal Marketing Fakultas Ekonomi, Kendari: Universitas Haluoleo

Zeithaml, V.A., M. J. Bitner. 2013. Service Marketing: Integrating Customer Focus Across the Firm 6 th ed. McGraw-Hill. Boston.

Zeithaml, V.A., Bitner, M. J. and Gremler, D. D (2006).Service Marketing (4th end). New York: The MC Graww-Hill Companies, Inc. 